\title{
EDITORIAL
}

\section{A Student's View of Student Motivation}

\author{
Cheryl Toby, BA \\ Park University
}

What motivates me as a student at Park University? As I have progressed in my education here, my answer to this question has changed, as my motivation has evolved from the extrinsic goal of earning grades into the intrinsic one of learning and growing as an individual and as a community member. Learning is a lifelong process I highly value, and will continue to be such beyond my graduation from Park. It is this intrinsic desire for learning that holds the strongest power of motivation for any student. Throughout my undergraduate experience, I have been taught by many outstanding faculty who have nurtured my love of learning. They have challenged me to stretch myself beyond my comfort zone and to do more than I thought I could do. A few, however, have been more of an obstacle to than a launching pad for my learning. What is the difference between these two groups of instructors? Highly effective and motivating instructors make connections between course content and students' experiences and real lives. They are passionate about their field, and they hold students to high standards as they challenge them to work hard and do their very best.

The effective, intrinsically motivating instructors I have had have fostered connections between course content and my own experiences and life. Why is your course content relevant for students? Why should they learn it? These are provocative questions any teacher should consider and be prepared to answer for students. Effective teachers go beyond simply answering these questions; they weave the connections throughout their instruction and assessments. We as human beings have innate curiosity about our world. The value of learning goes beyond reaching career goals. As children we eagerly explore and question everything around us. As we progress through our formal education, this curiosity is often crushed. We

When instructors take time to reflect on the relevance and value of their course content and instruction, they create the opportunity to fan the flames of students' natural curiosity. lose the joy and value of learning: We may begin to simply jump through the hoops placed before us to win the prize we are seeking-a grade or credit for a particular course. We may not recognize the personal value of some courses we are required to complete for our degrees. When instructors take time to reflect on the relevance and value of their course content and instruction, they create the opportunity to fan the flames of students' natural curiosity. Personal connections to content are powerful motivators for learning.

Passion for their field is another characteristic of highly effective, intrinsically motivating instructors. The teachers I have learned the most from have been excited about and committed to their discipline. Their enthusiasm carries through in their instruction and is contagious. Nothing is more damaging to motivation than an instructor who is bored with his or her own material. Every instructor has their own individual personality and teaching style, but can share in common a passion for their discipline and course content. Why did you choose your field? What excites you about it? What fascinates you? What do you still want to learn about it? These are questions I hope you as faculty never stop asking. The answers to these questions can fuel your passion and the enthusiasm you share with your students. If you are no longer passionate about your field, how can you expect your students to care about it? Your passion for your discipline is a strong motivator for your students.

Finally, the expectations you hold for students set the bar for what you will get from them. Do you have high expectations, or do you simply want to get them 
through the semester? To feel competent, and to be challenged, are two highly motivating human needs for every individual. When instructors hold students to high standards, they challenge us to stretch ourselves and grow. The need for challenge, however, must be balanced with the need to feel competent. Students need instructional support to meet your high expectations. We must believe we can be successful. The most effective teachers I have had created positive, supportive learning environments. They had clearly defined criteria for success. They also provided ongoing, personal, and specific feedback on my performance and the areas I needed to continue to grow in. They communicated positive expectations for students' success, but they were unyielding on the quality of work they expected. Make our success meaningful. Hold us to high standards and support our efforts to reach beyond ourselves and to grow in our knowledge, understanding, and skills. You will then motivate us to work hard to meet your expectations.

As faculty at Park University, you touch the lives of your students. You contribute to who we will become and the impact we have on our community and the world. Each course we take changes us and our view of our education, the world around us, and our place in it. Each semester, you have the opportunity to launch your students on a journey of learning. Make connections between your course content and your students' lives. Be passionate about your field.

Make our success meaningful. Hold us to high standards and support our efforts to reach beyond ourselves and to grow in our knowledge, understanding, and skills. You will then motivate us to work hard to meet your expectations.

Hold high expectations for us and challenge us to work hard and do our very best. Then you will help us develop an intrinsic desire for learning. Remember when you too were a student: What were the qualities of instructors who most motivated you? The answer to that question will provide insight into your own students' motivation.

Toby is an elementary education major at Park University; her career goal is to become an elementary classroom teacher and to nurture her own students' love of learning. She completed her student teaching in spring 2007 and will graduate in May 2008. Toby lives in Kansas City with her husband and two sons. 